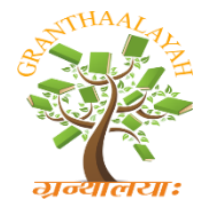

INTERNATIONAL JOURNAL OF RESEARCH GRANTHAALAYAH A knowledge Repository

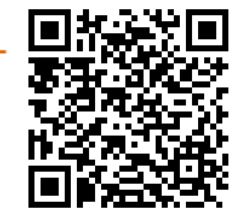

Management

\title{
ISLAMIC DEVELOPMENT MANAGEMENT PROGRAM IN THE INSTITUTIONS OF HIGH LEARNING WITH SPECIAL REFERENCE TO NEGARA BRUNEI DARUSSALAM
}

\author{
Mahayudin Hj Yahaya ${ }^{* 1}$ \\ ${ }^{* 1}$ Ph.D, Sultan Sharif Ali Islamic University, Spg 347, Jalan Pasar Baharu, Gadong, Bandar Seri \\ Begawan BE 1310, Negara Brunei Darussalam
}

\begin{abstract}
This study examined the term of 'Umran made by Ibn Khaldun in the 14th Century A.D. with the aim to compare with other terms, notably civilization and urbanization practiced by modern society in the context of development and management. The objective of the study is to identify the triangular theory of universal prosperity (ToUP/Umran/) to be implemented according to the current situation and circumstances in line with the demands of Shari a Law in Negara Brunei Darussalam. Among the focus of the study is the definition of ToUP, its resource, principles and ultimate goals for the welfare of human beings and universal prosperity. The study concludes that the Theory of Universal Prosperity is the base of the tree of all the problems that affect every aspect of human life whether in culture or civilization.
\end{abstract}

Keywords: Triangular Theory; Universal Prosperity; Development Management; Islam; Brunei.

Cite This Article: Mahayudin $\mathrm{Hj}$ Yahaya. (2017). "ISLAMIC DEVELOPMENT MANAGEMENT PROGRAM IN THE INSTITUTIONS OF HIGH LEARNING WITH SPECIAL REFERENCE TO NEGARA BRUNEI DARUSSALAM." International Journal of Research - Granthaalayah, 5(7), 315-337. 10.29121/granthaalayah.v5.i7.2017.2138.

\section{Introduction}

There are two institutions of higher learning in Malaysia to offer Islamic Development Management Program. First, Universiti Sains Malaysia which handles the program and categorizes it under the control of Islamic Development Management Studies Centre or Centre for Islamic Development Management Studies (ISDEV). ISDEV has been offering post-graduate study program (Postgraduate) at the masters and doctorate. Second, Kolej Universiti Islam Melaka (KUIM) which has offered the program and placed under the control of Islamic Studies Academy (API). API has been offering study programs at the undergraduate and grants Bachelor of Islamic Development Management with honors. Subsequently, UNISSA added another, namely the Faculty of Islamic Development Management UNISSA (FPPI) and started operations on 2nd January 2017. 


\section{Theory of Islamic Development Management}

In the field of management and development of Islam, there are three philosophies practiced by Islamic countries in the Malay regions of the world.

- Theory of Tamadun (Arabic: Tamaddun; English: civilization): Tamadun Theory associated with the achievement of progress in the city. The word "tamadun" is a direct translation of the English word civilization. The word stems from the Latin civilization, namely the combination of three words: civis (citizen), civilis (city), and community (life in the city). The term "civilization" has been used in Malaysia since the British colonial era to the present day. From the word civilization was born the terms "Tamadun Melayu" (Malay Civilization), "Masyarakat Madani" (civil society), and "Islam Hadhari" (civilizational Islam). In the Arab countries called Hadarah Islamiyyah which gives the same meaning, namely "Islamic civilization".

- Theory of Peradaban (Culturalization): This theory is associated with Islamic civilization or the peradaban of Islam. The word "peradaban" comes from the Arabic word "adab" (courtesy). Islamic civilization is interpreted as a cultured and courteous civilization. For these reasons it is more in line with the word "civilization" is created for the purpose of this term is to Islamize "civilization" that is considered a "secular". The term "peradaban" was adopted and popularized in Indonesia since the 1950s until today.

- The Theory of 'Umran (Islamic prosperity). The theory of 'Umran specially created by Ibn Khaldun to replace Civilization, the creation of the West. The philosophy of 'Umran has its own methodology based on three main things, as stated in al-Qur'an al-Karim. The Word of God:

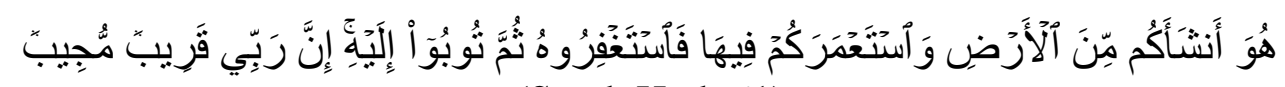

(Surah Hud: 61)

From this verse we find that there are three main issues which are fundamental to the management of the development of Islam in al-Qur'an al-Karim, which are as follows:

First, Allah (huwa): He is Allah Subhanahu wa Ta ala, the Creator the Almighty who created the heavens and the earth and all that is between them.

Second, Human ('an sha 'akum): He makes you (mankind) on the earth (clay) and appoints you as the "Caliph of Allah on earth" and is responsible for the prosperity of the earth according to His will, that is Allah Subhanahu wa Ta'ala, and obey laws and regulations that He has created for you without creating destruction. If you create destruction, then you should immediately ask for forgiveness, and repent, Allah Subhanahu wa Ta'ala always be with you and mercy.

Third, Earth $(a r d)$ : God made man on the earth (clay) and all creatures that are on the earth, animals and plants and made it a source of sustenance and life for mankind to live in peace and prosperity and perform acts of worship to Allah Subhanahu wa Ta 'ala to be rewarded in the hereafter. 
From the above explanation it is clear that the aspects of management and development from the perspective of the al-Qur'an is based on the concept of the triangle, which is God, man and nature, and all three of these elements are interrelated and can not be separated from one another in a developing country, and at the same time, a milestone in the life of 'Umran. Therefore, the text will be the basis on the theory and philosophy of the Faculty of Islamic Development Management UNISSA to strengthen the concept of Dhikr Nation and Vision 2035 in Negara Brunei Darussalam.

\section{TAMADUN-PERADABAN UMRAN}

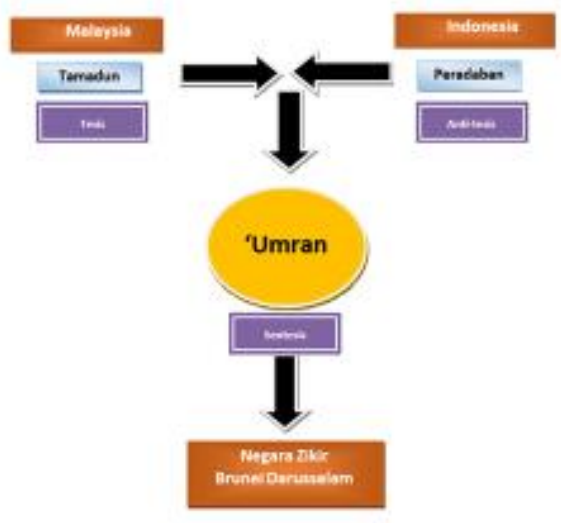

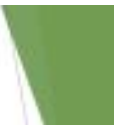

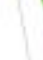

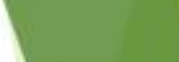

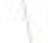

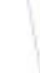

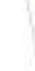

(1)

1

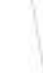

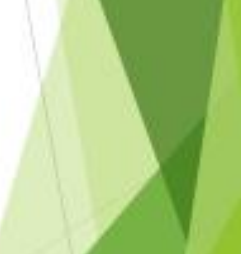

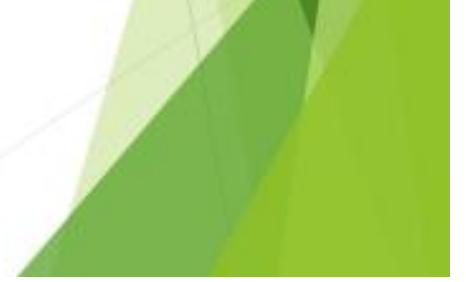

There are ten things pertaining to God (the Creator), nature and human beings, as follows:

- The concept of Uluhiyyah - this quality devote themselves to God Almighty, Almighty, and the Wise, and no partner, and He makes all creatures, whether in heaven or on earth, visible to the eyes and not. He has sent prophets and apostles and the holy scriptures of the Torah, the Gospel, the Psalms and al-Qur'an al-Karim as a guide for mankind towards nature with the day of reckoning.

- We, as servants of God cannot lie to God because God created us, and to Him we surrender. God created the universe for human life and worship God, society and country.

- Man's relationship with God, human relations among people, and between people and nature are always intertwined. Thus, God, man, and nature are in the chain and "TriangleThree", and the three are inseparable from one another.

- Allah Subhanahu wa Ta 'ala is the one who created all living things whether in the sky or on the earth together with the laws of nature which is protected and maintained by his power and 'inayah.

- Mankind as a servant of Allah is commanded to obey the laws and regulations set by Allah. At the same time, Allah has stated "Mankind who is created from the earth (clay) is commanded and entrusted to develop and prosper the world" هوانثأكم من الأرض واستعمركم فيها 
- $\quad$... and thereafter it is commanded of them to seek forgiveness and repent towards Him فاستغفروا ثم توبوا إليه..

- There are three important factors mentioned in the above verse, that is, Allah mankind and the earth (environment) are the main focus of development.

- The theory of 'Umran is created specifically to manage mankind and natural resources for the purpose of development based on the philosophy of Islamic Management and development which is characterized as holistic, amalgamated, hands-on, and in line whether in theory or practice.

- It is implemented in the form of a triangle, starting from faith in Allah, followed by efforts by humans on the management of the environment for the purpose of development.

- In the context of development, it is required to have a leader, administrator and manager who is efficient, honest and trustworthy to ensure that the objective of development is achieved.

- To ensure that the objective is achieved, they require a yardstick to act as an index to measure the extent of the development achieved. The tool used is Key Performance Indicator (KPI) in the area of development, and Total Quality Management (TQM) in the field of management.

The real world consists of the heaven, earth and space which own a control system that controls all the occurrences in the heavens, on earth and in the skies. The sun is the source of life that illuminates the entire universe to provide life for the plants and all creatures that are in the earth. The moon functions at night to provide a course of light for the life of plants and crops and provides a maneuver for people who are traveling in the evening. The stars and planets are scattered in space and also helps in the effort to develop a variety of companies through geography and knowledge on falak (astronomy) to determine a time and location suitable for construction. Environment: contains elements flora and fauna which has an influence upon development.

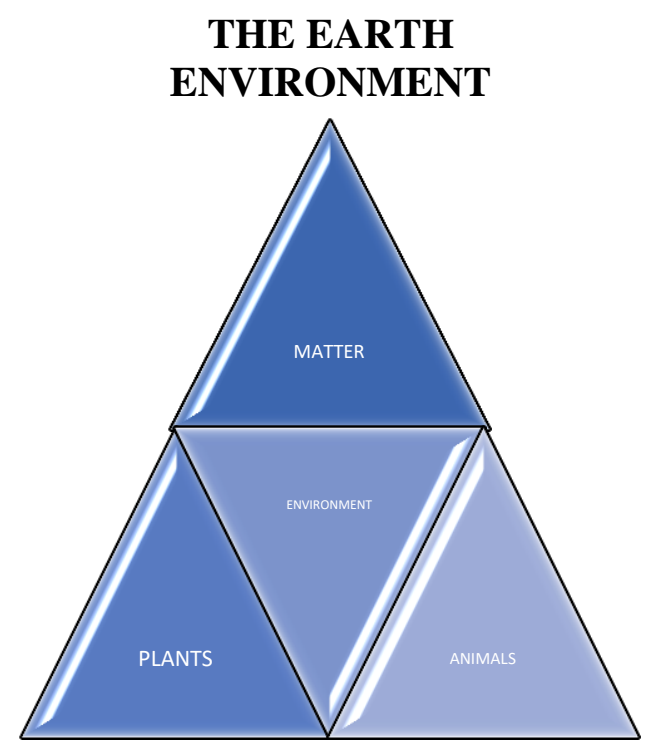

${ }^{1}$ Al-Qur`an, Surah Hud: 61 


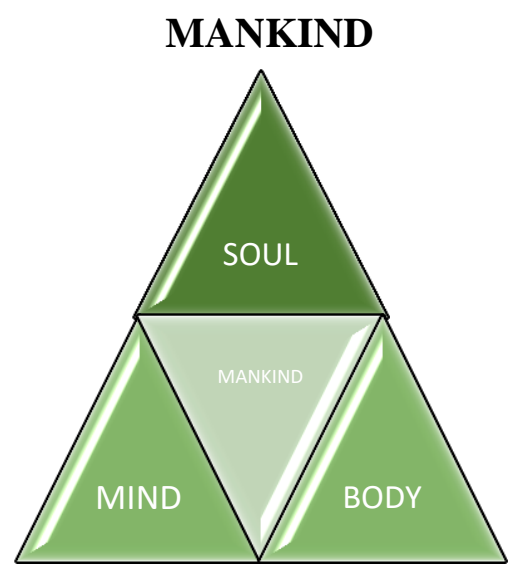

Humans possess spirit, mind and body, and its function has an influence upon development. Human beings make history. History consist of past events produced by man and society and from history, culture is born. Culture is the traditional practice involving hereditary religious beliefs, language and customs. From culture thereafter civilization is born. Civilization is the progress achieved by humans in a physical form. When Islam came, the aspects of civilization are filled with religious teachings and morals, the combined results of these three items generate 'Umran and thus the Theory of Universal Prosperity, "Nazariyah 'Umran `Alam" (ToUP).

\section{THEORY OF UNIVERSAL PROSPERITY (ToUP)}

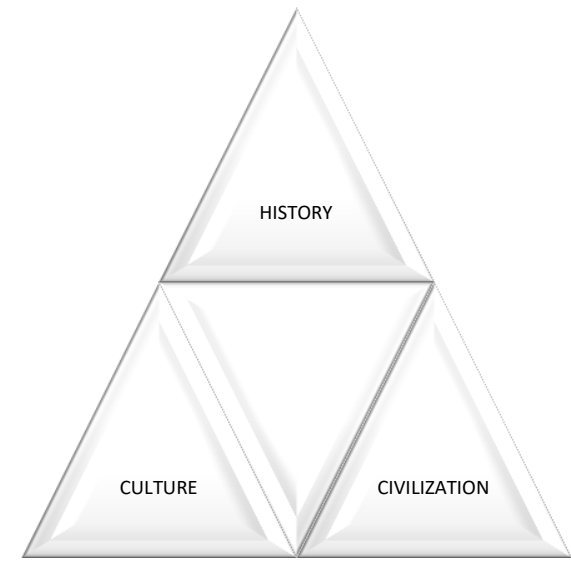

\section{SOURCE OF THE THEORY OF UNIVERSAL PROSPERITY}

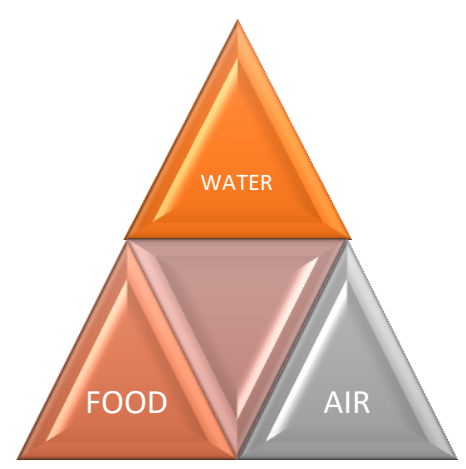


Water: the source of life and function in the development and the prosperity of human and the environment.

Food: obtained from natural sources is fundamental in human life. For the people of Islam require legal food (halal), clean, fresh and nutritious (tayyiban) for maintaining a healthy physical, mental and spiritual in life to prosper in this world and hereafter.

Air: that collected from the surrounding is a source of life shared by all who are on earth. Air is also the virtual technology that provides a lot of convenience for people, especially in the field of communication.

\section{THE PRINCIPLES OF TRINGULAR THEORY OF UNIVERSAL PROSPERITY}

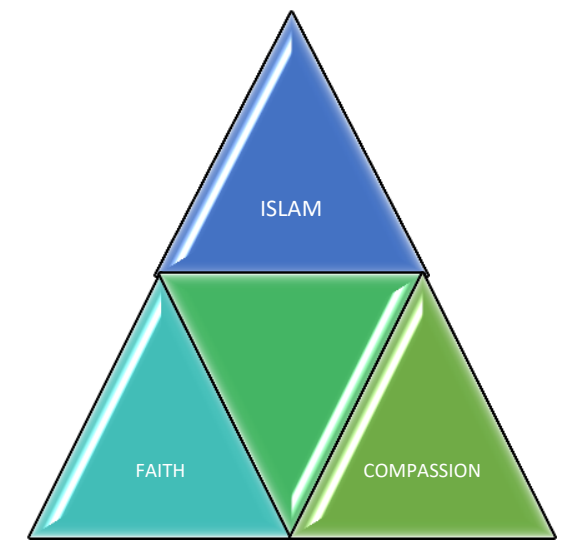

Islam is the religion of Allah and how to live a full and a complete way of life that involves two aspects of life, both internal and external. The internal aspect is to believe in Allah, the angels, the scriptures and the messengers. The external aspect is the relationship between a human with Allah (hablun min Allah) and the relationship between a human with other humans (hablun min nas) and the human relationship with the environment as a source of life. Both the external aspects can be termed as a compassion. Thus, with this triangular theory can completed the life of a Muslim. These three aspects are also made in the form of belief ('aqida), shari`a (shari`a law) and conduct (akhlaq) as specified below:

\section{THE BASIC PRINCIPLES FOR TRIANGULAR THEORY OF UNIVERSAL} PROSPERITY

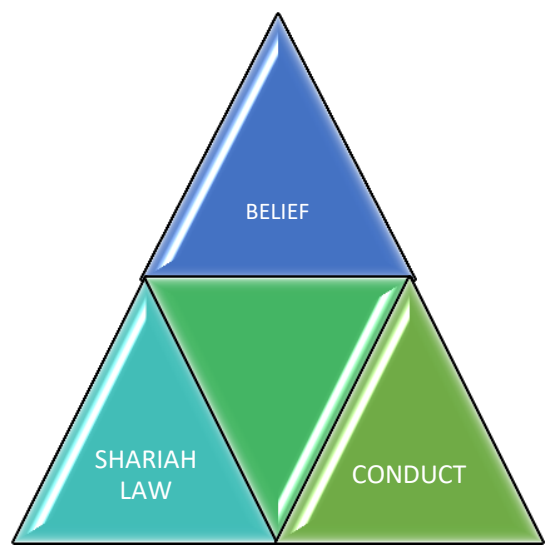


Belief: the basis for holding that a Muslim believes in Allah, the Angels, the Scriptures (i.e the Taurat, the Injil, the Zabur and the Qur'an al-Karim), the Messengers, the Day of Judgment, and the Pre-Ordainment. Aspects of faith gives strength and faith to Muslims to work and fulfill the commandments of Allah, including the management and development of society and the state.

Shari'a': the law and regulation laid down by Allah Subhanahu Wa Ta'ala to manage human life in accordance to the ways of Al-Quran and Al-Sunnah. It is divided into into several areas which are worship (prayer, fasting, perform zakat, perform haji), Mua'malat (administrative business, trading, financial and others), Munakahat (marriage) and jinayat (prevent crime and others).

Conduct: the function of morality in life and for the development of the ummah include the aspect of communication, respecting the neighbours, trust, tolerate, cleanliness, not only within islam but also within humanity and the surrounding environment. All of this must be kept and maintained properly and responsibly so that their rights are fulfilled.

\section{THE ULTIMATE GOALS OF TRIANGULAR THEORY OF UNIVERSAL PROSPERITY}

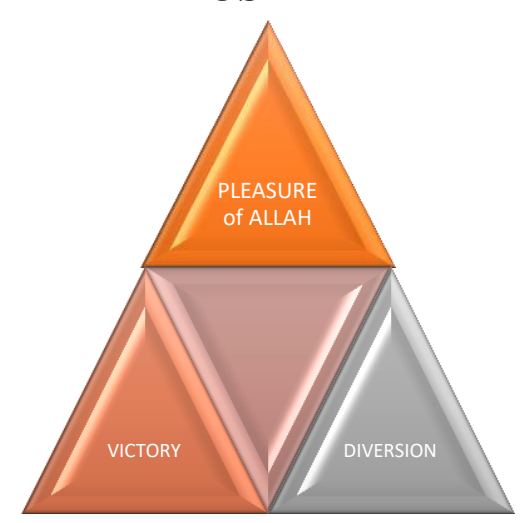

Pleasure of Allah Subhanahu Wa Ta ala is needed in order to ensure success of well-being in this world and rewards in the hereafter.

Victory: Advanced progress and development in terms of spiritual, mental and physical aspects within the context of this world.

Diversion: In the hereafter in terms of obtaining the pleasure and mercy of Allah Subhanahu wa Ta ala for all the deeds and charity that have been done in the world will be rewarded to enter paradise.

THE SCIENCE OF TRIANGULAR THEORY OF UNIVERSAL PROSPERITY

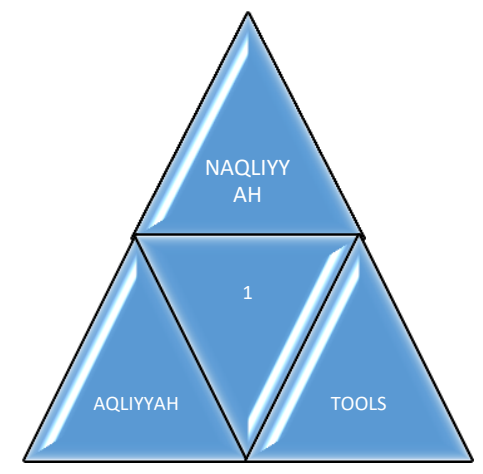


The Science of 'Umran is divided into three areas, which is 'ulum naqliyyah (religious knowledge), 'ulum 'aqliyyah and 'ulum lughawiyyah. Each of these areas of knowledge contain numerous types of sources and functions.

- 'Ulum naqliyyah is the religious knowledge sourced by the revelation that is contained in ayat muhkamat (clear defined and have section, methods and functions)

- 'Ulum 'aqliyyah is the academic knowledge sourced by understanding that is contained in ayat mutasyabihat which have unclear definitions and meanings and it also has divisions, methods and functions.

- Tools ('ulum lughawiyyah) is knowledge of languages or knowledge of equipment relating to communication and connections between the fields of knowledge that have been studied, whether it is religious knowledge or academic knowledge. Example, the function of Arabic language is to read and understand the holy Quran, the prophet' hadiths and religious books. The function of English language is to understand the knowledge of science and technology. Malay language is to understand the Malay's customs and traditions. Aside from that, the function of languages are to communicate between individuals and to form an understanding and cooperation among society to build a community and nation.

\section{THE SOURCES OF TRIANGULAR THEORY OF UNIVERSAL PROSPERITY}

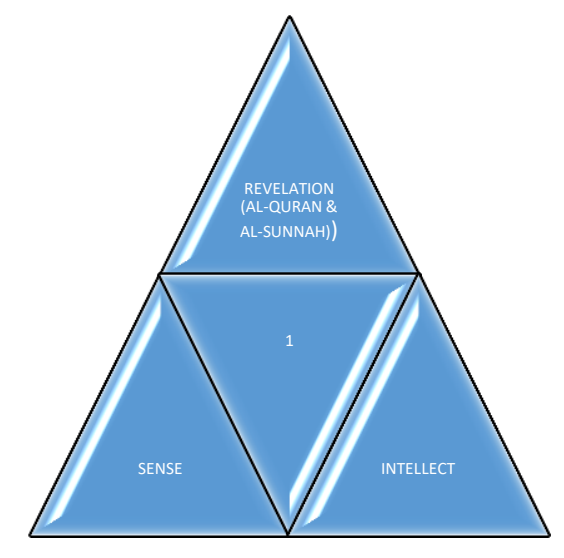

Knowledge: include the definition of science, philosophy of science, view of the ancient Islamic scholars on science.

1) Revelation: as the main source of knowledge contained in the verses of al-Quran. There are two types of verses in the Quran: First, the decisive paragraph. Secondly, the allegorical paragraph. The decisive paragraph tells the story of a definite religious knowledge. The allegorical paragraph revolves around the sciences of logic that are not obvious and require a study based on the hadith of the Prophet and the scholars view as a guide.

2) Intellect: is a source of knowledge after the apocalypse. Scholars interpret Islam to use common sense to determine if the law has no clear evidence either in the Quran or Hadith. Sense can be used to explore the subject of knowledge either through social sciences and humanities or pure science for development.

3) Sensory: a third source that involves members of the human body and the physical world to assist and strengthen the sources of revelation and reason for the development of society and the state, especially if there is no clear verse in the Quran and Hadith. 


\section{TYPES OF RESOURCE TRIANGULAR THEORY OF UNIVERSAL PROSPERITY}

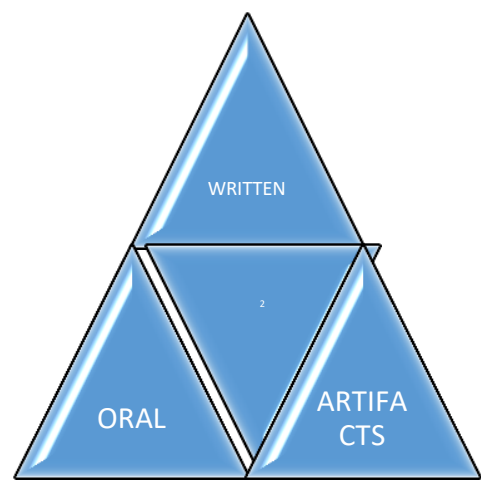

Resources: knowledge is gained through three types of resources: written sources, oral sources and materials of historical relics (artifacts).

1) Written sources are located in two states: first, a handwritten manuscript of such documents, correspondence, agreements, work, etc., and the second, printed (print media), such as books, journals, newspapers, and other.

2) Oral sources are obtained through word of mouth (oral history), or through interviews and electronic media.

3) Artifacts, relics of history, such as tombstones, currency, building, monument, sculpture, etc., which contains information on the history of the past.

\section{THE METHODOLOGY OF TRIANGULAR THEORY OF UNIVERSAL PROSPERITY}
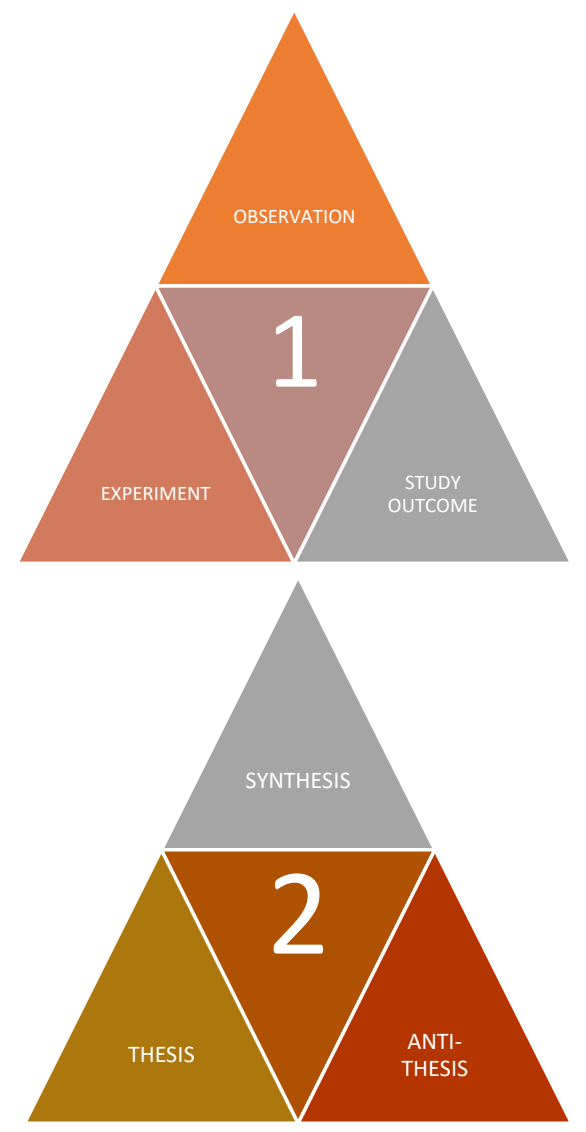
To prove that the knowledge of 'Umran works, we use the method of induction via semantic methods, analysis and comparison based on social science methods through data collection and the methods of physical science through observations as evidence to obtain a concrete outcome Scientific induction method is carried out in two ways, as follows:

1) Conducting the survey through three stages, namely:

a. Thesis (first study),

b. Antithesis (second study), and

c. Synthesis (third study), taking into account the results of the first and the second study to determine the results of the study were balanced and concrete. This study is often used in the social sciences.

2) Conducting the survey through three stages, namely:

a. Observation,

b. Experiment, and

c. Revision (second experiment) to determine concrete results. This method is applied in the field of natural sciences.

\section{Execution of Triangular Theory of Universal Prosperity in FPPI}

Faculty of Islamic Development Management (FPPI) UNISSA will introduce a Program on the management and development of Islam based on the theory of welfare provision ToUP (Theory of Universal Prosperity) and will offer both programs for undergraduate and post-graduate session of studies starting in August 2017/2018 for the purpose of producing graduates who are highly skilled in the field of knowledge of management and the development of Islam, not only in theory but also in practice. The aim is to handle the issues of development and management in a more effective way in line with the current needs in the era of globalization. When this happens, the FPPI itself will create its own history to realize the method of Islam in the form of "sythesis" the coherence between knowledge which is naqli (revealed knowledge) and aqli (intellectual knowledge) and will be implemented at the Undergraduate and Post-Graduate levels in the form of Theoretical and practical "hands-on" in the field of management and development of Islam.

With the completion of the integration of theoretical and practical work in the field of management and development of Islam, hence FPPI is the region's premier construction management program that offers complete and comprehensive Islam based teachings of Islam that is "holistic". In this case, the Triangular Theory of "Umran will also be introduced as a platforms for the Philosophy of FPPI, UNISSA and thus become a niche university in that area.

\section{The Fields of Triangular Theory of Universal Prosperity Study in FPPI}

The courses offered at the Faculty of Islamic Development Management (FPPI), UNISSA covers three areas: political, social and economic. From these three areas there will be nine sub-sectors, three in the political field, three in the social field and three in the economic field. The division is as shown in the following figure: 


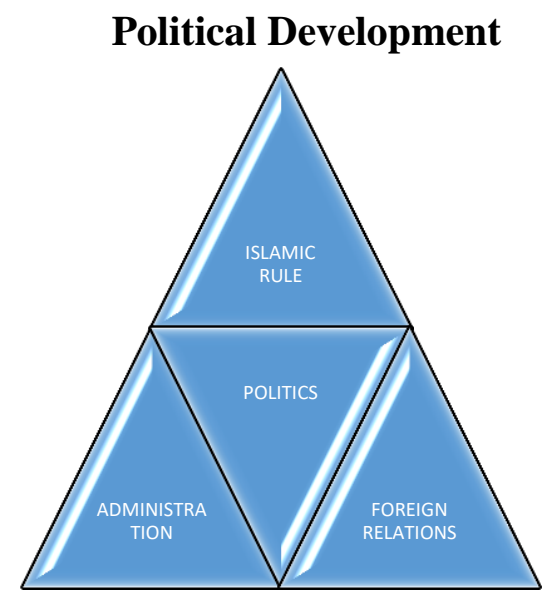

\section{Politics:}

1) Islamic rule: Islamic political system, began in the time of Prophet Muhammad allubale, followed by the Rightious Caliphs, Umayyad Caliphate, Abbasid Caliphate, the Spain Islamic Kingdom, the Ottomans, and the Islamic kingdoms thereafter, including the Sultanate of Brunei.

2) Administration: Islamic administrative system, the type and manner of implementation of Islamic administrative system in the past and present. Starting with the Islamic government of Medina at the time of the Prophet Muhammad aلd followed by later generations thereafter. It involved the administration and management of Baitul Mal, Wakaf properties, Tax, Zakat, finance, law courts, and so on and so forth.

3) Foreign relations: Diplomatic relations with foreign countries in terms of political, economic, social and education matters. Prophet Muhammad allwate initiated these relations followed by the Rightious Caliphs, Umayyad Caliphate, Abbasid Caliphate, the Spain Islamic Kingdom, the Ottomans, and the Islamic kingdoms thereafter, including the Sultanate of Brunei.

\section{Social Development \\ Religious Beliefs}

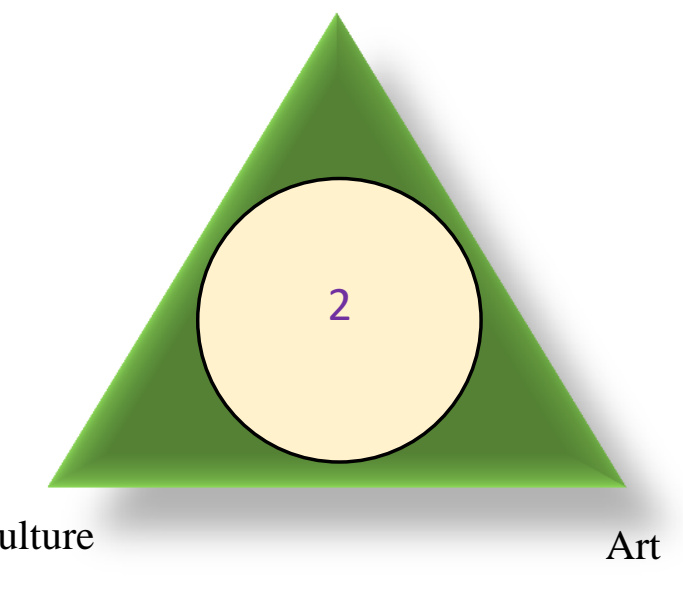




\section{Social:}

1) Religious Beliefs: includes a variety of beliefs / religion professed by many people including Hinduism, Buddhism and the difference between Abrahamic religions. Judaism, Christianity and Islam professed by Muslims. Particular focus is on the religious beliefs of Islam as the basis of the management and development of Muslims.

2) Culture: includes a variety of cultures, including language and traditions passed down from generation to generation and its implications within the lives of Muslims.

3) Art: definition, Islamic art, type and category of Islamic art such as calligraphy, sculpture, musical instruments, and others.

\section{Economic Development}

Trade

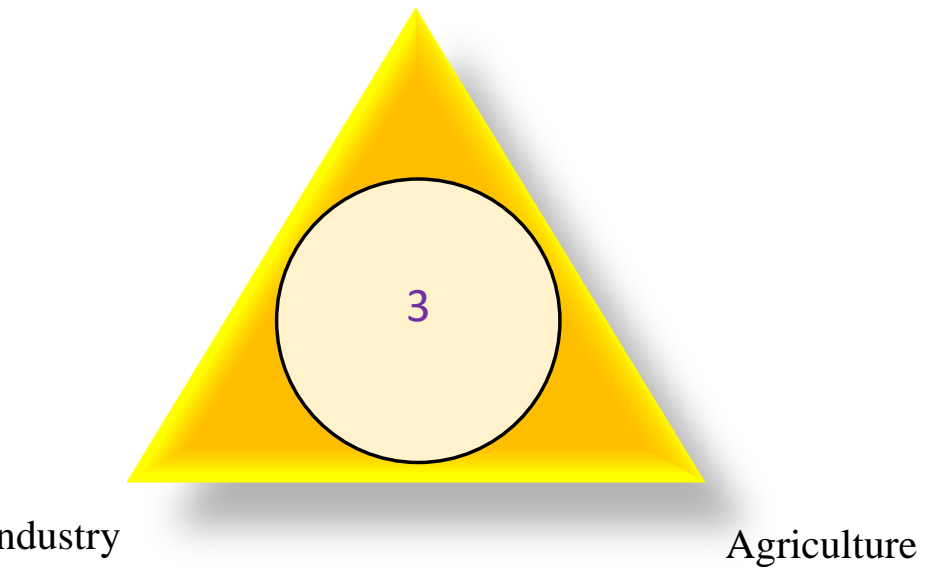

Economy: Islamic economics, economic history of Islam and the implementation of past and present, beginning at the time of Prophet Muhammad allwaste followed by the Rightious Caliphs, Umayyad Caliphate, Abbasid Caliphate, the Spain Islamic Kingdom, the Ottomans, and the Islamic kingdoms thereafter, including the Sultanate of Brunei.

1) Trade: types of goods traded, subscribed and consumers and economic history of trade in Islam. Communication: by sea, land and air.

2) Agriculture: Definition, agricultural aspects, types of agriculture, farmers, entrepreneurs, suppliers and consumers.

3) Industry: heavy industry and light industry, the public sector and the private sector.

\section{Leadership}

\section{Honesty}

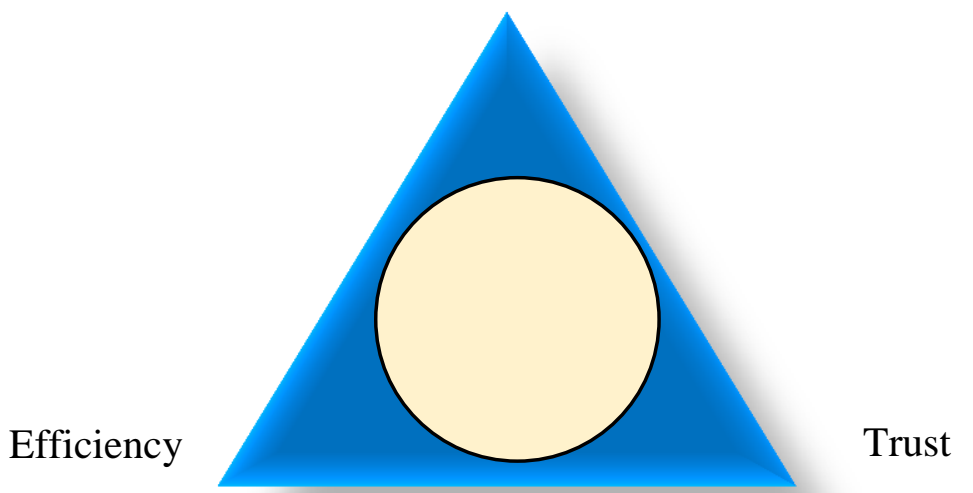


Leadership: the definition of leadership, leadership in Islam, the nature of a leader such as honesty (righteousness), efficiency and proficiency (knowledgeable) and trust in managing and developing the state and society.

1) Honesty: to be honest, sincere or true in all actions, which are made by providing a clear sample among Muslim leaders earlier, and its impact in terms of management and development.

2) Efficiency: has a direct relationship with knowledge and skills with experience in any course of knowledge and sector building that explored.

3) Trust: definition, for example, trustworthy among previous Islamic leaders with its impact and influence.

\section{MANAGEMENT OF TRIANGULAR THEORY OF UNIVERSAL PROSPERITY IN} FPPI

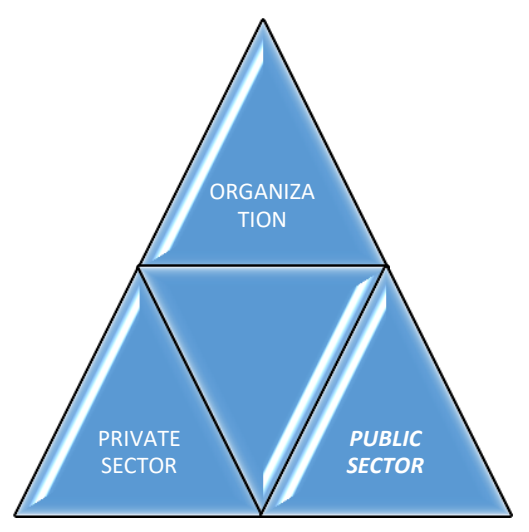

Management: an important aspect in building course, especially in the economic course. In that theory, the method and the implementation management technique should be learned and understood to produce trained workers, skillful, innovative, creative and productive. This is involved public sector and the private sector.

1) Organization: an administration central and building management that takes charge giving instruction and a guide to workers in managing and implementing development effectively and efficiently based on the Islamic organization management system. This involved in the public sector and the private sector.

2) Public sector: provides human resource, management system and implementation of the strategy of short term, medium and long term.

3) Private sector: provide a source of energy, work, and financial management system, as well as short-term policies and strategies, medium and long-term. 


\section{DEVELOPMENT OF TRIANGULAR THEORY OF UNIVERSAL PROSPERITY IN FPPI}

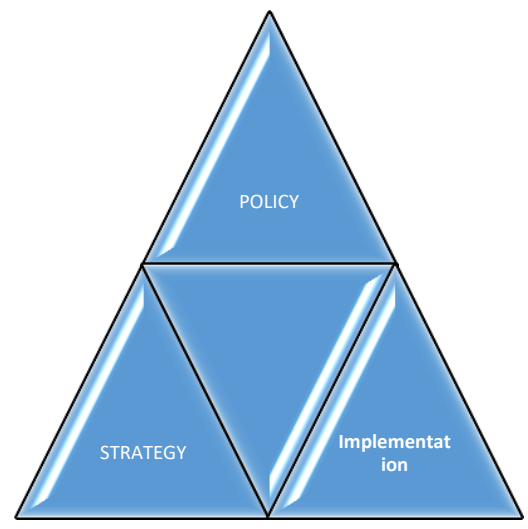

Development: meaning development from an Islamic perspective, the scope of development: physical and non-physical.

Policy: Islamic Development policy involving laws and employment in line with the law and the needs of the Islamic nation.

Strategy: strategic development are the steps to be taken to implement development policies.

Implementation: a motion of positive work in the form of hands-on practical implementation including work ethic, traits honest, efficient and trustworthy. ${ }^{2}$

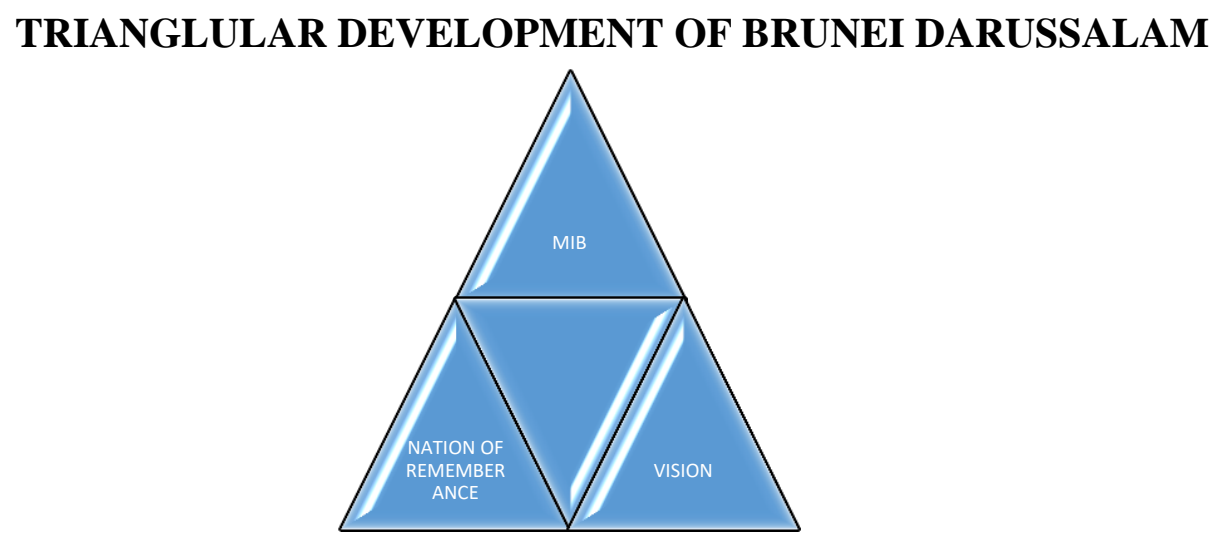

MIB (Malay - Islam - Monarch): a philosophy of Brunei Darussalam in terms of political, economic and social, and it continues to be practiced since the beginning of the advent of Islam until present.

\footnotetext{
${ }^{2}$ Further information about FPPI's Development`s policies and strategies. See Mahayudin Hj Yahaya "IslamicBased Development's Policies and Strategies: From Faculty of Islamic Development Management Perspective", International Journal of Education and Human Developments, Vol.3 No.2:Much 2017, pp.31-37.
} 


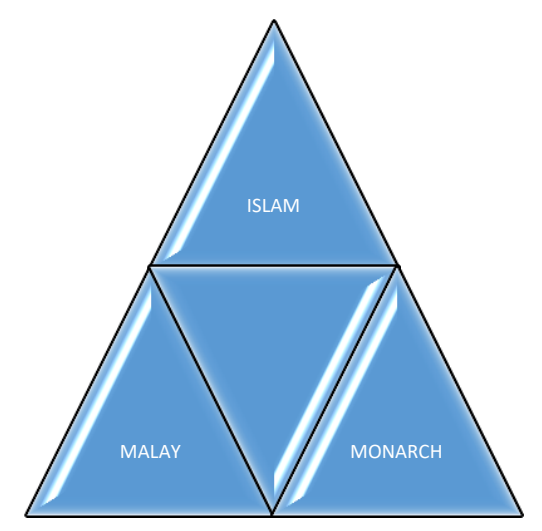

MIB:

1) Melayu: refers to the nation, language and culture of the Malay community that acts as a catalyst for the political, socio-economic of upbringing and development, and thus becomes the front runner to the political and socio-economic upbringing and development of the country of Brunei Darussalam.

2) Islam: serves as a development milestone and sets a balance between traditional practices of the public and the Government Monarchy system; both are implemented in accordance with Islamic law.

3) Beraja: refers to the system adopted by the Monarch of Brunei Darussalam since its establishment comment at the time of Sultan Muhammad Shah to this day and it will continue and remain to uphold the beliefs of Islamic law.

\section{The Triangular Development in Negara Zikir (Zikir Nation)}

Negara Zikir (Zikir Nation): connotes an Islamic state based on the belief of Ahl al-Sunnah wa al-Jama'ah and Shâfi î sect. Zikir (dhikr) in the al-Qur'an contains two meanings, the first meaning is "remembrance of Allah" and the second meaning is "knowledge". Both definitions have joined to implement "Negara Zikir" in an indefinite time period.

Negara Zikir is the combination of two words "negara" and "zikir", both defined as follows:

1) Negara in the context of Islamic history synonymously with "dawlah". According to the dictionary of the Arabic language, such as Lisān al-'Arab, Qāmūs al-Muhìt and al-Mu 'jam al-Wasit, the word "negara" is synonymous with dawlah, while "tatanegara" means the country's legal system (nizāam al-h̆ukm).

The word dawlah comes from the root word dala - yadulu - dawlah which means alternate, distribute and circulate. These words can be interpreted as a nomadic social group from one area to another and finally settled in the territory administered by a government to regulate and protect the interests and welfare of the people. Al-Kindi (185-256H / 810-869M), a famous Muslim philosopher and the first person of Arab descent has defined dawlah as synonymous with mulk (power). Generally, dawlah can be construed as state, administration, government or dynasty. 
In al-Qur'an there are two verses that mention the word that seems to be similar to the word dawlah which is dülah which means "rotating" and "circulating". The first verse in Surah Al 'Imran (3), verse 140. Allah said:

Which means:

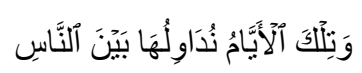

"And these days [of varying conditions] We alternate among the people"

The second verse in Surah al-Hashr (59): 7, Allah says:

Which means:

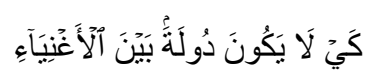

"so that it will not be perpetual distribution among the rich from among you"

When examined the contents of the two verses above, it appears that the first verse connotes political matter whereas the second verse connotes economical matter.

The word dawlah means administration which had not been adopted in the days before Islam or the early days of Islam. It was first used during the reign of the Abbasinian dynasty.

In those days, the word Dawla was construed as a "victory" and "turn" to continue the power formerly as an Islamic state under the rule of the Umaiyyah. This time they said it was the turn of the Abbas family (dawlah Abbasiyyah). The title Dawla was given to Hasan bin Hamdan and Ali bin Hamdan and both of them are from Umaiyyah who ruled Mawsil (Mosul) and Syria who bears the title of "Sayf al-Dawlah" (sword of the state). This title continues to prevail in the reign of Bani Buwaih $(945 \mathrm{H} / 1086 \mathrm{M})$ and the government of the Persian dynasty and Ghaznawi Turkish dynasty that dominated the area of Central Asia and parts of South Asia with the central government in Ghaznah who ruled between 1008-1186M. The term continues to be used by the Fatimiyyah who ruled North Africa (909-1171M) and al-Muluk the government Tawā'if of Spain (1011-1086M).

2) Zikir (dhikr) in terms of language means "call", "remember", "appointed" or "refers to ${ }^{3 \text { ". For }}$ example, the name of Allah "dhikrullah" (with tongue), remember Allah "dhikrullah" (with the heart), refers to the righteousness of Allah "dhikrullah" (with reason) and refers to the law of God "dhikrullah" (in general).

The combination of words: "Negara" and "zikr" gives a meaning of "a country that articulates remembrance and shows Allah's truth and refers to His laws and rules". From these words, they expand the variety of interpretations of "Negara Zikir". There are various interpretations that have been given by religious leaders and Islamic scholars on "Negara Zikir", which are as follows:

According to Pehin Datu Seri Maharaja Dato Paduka Seri Setia (Dr.) Ustaz Haji Awang Abdul Aziz Bin Juned, State Mufti of Brunei Darussalam, the Negara Zikir mean:

\footnotetext{
${ }^{3}$ Al-Mawrid, Kamus Arabic-English. 1988. Dr. Rohi Baalbaki. Beirut (al-Tab`ah al-Ula): Dar al-'Ilm li al-Malayyin,
} 
"The country, where many people do zikir; a country, which is always lively and rich with His remembrance; countries, developed and administered by remembrance; countries, which protected and preserved the remembrance of Allah. "Negara Zikir" is a state-oriented and molded by remembrance: political remembrance of Allah, economic remembrance of Allah, social remembrance of Allah, defensive remembrance of Allah"'4.

Pengiran Dato Seri Setia Dr. Haji Mohammad bin Pengiran Hj Abd. Rahman, Minister of Religious Affairs of Brunei Darussalam, defines the Negara Zikir as:

"..." A certain place or area that has a legitimate boundaries, inhabited by a group of people, has laws and has a government and has sovereignty. Brunei Darussalam meets these criteria.

'Zikir' is derived from the Arabic language which means 'remember' "... Negara Zikir is," a nation where its citizens remember a God. God is Allah Subhanahu Wa Ta'ala and this is not based on other religious beliefs. "Negara Zikir" is an Islamic country that adheres to the Islamic teaching, practice and appreciation of the faith, as well as shari a law and morals. "

Yang Berhormat Pehin Siraja Khatib Dato Paduka Seri Setia Ustaz Haji Awang Yahya bin Haji Ibrahim also defines the Negara Zikir:

"As a country that implements acts of worship where remembrance is a point of reference and a basic practice of life within the state, which includes both social and private life". Generally, he said that "all kinds of acts of worship are zikir..."

Yang Berhormat Pehin Udana Khatib Dato Paduka Seri Setia Ustaz Haji Awang Badaruddin bin Pengiran Dato Paduka Haji Othman also said that the Negara Zikir mean:

"A community's beliefs to the teachings from Allah Subhanahu Wa Ta 'ala ; not forgetting Him and to be thankful for all of His gifts... as the citizens are remembering Allah and obeying His favors ${ }^{\prime \prime}$

Dato Paduka Awang Haji Jumat bin Haji Ampal was focused on youth culture and youth development as the basis for the construction of Zikir country with the quote:

"The Youth generation is the most valuable and important human resource in building a country. The potential of this generation is to act as the contributor for the growth of this nation and country is trusted worldwide ${ }^{6}$.

According to Ustaz Muhammad ' Uthman El-Muhammady, “Negara Zikir” is a:

\footnotetext{
${ }^{4}$ For further information, see Negara Zikir:Azam, Keperluan dan Perlaksanaan, compilation of working papers Seminar Negara Zikir, Majlis Ilmu 2008, Prime Minister Department, Negara Brunei Darussalam, published by , Prime Minister Department, Negara Brunei Darussalam, 2010, pp.. 3-20

${ }^{5}$ Ibid., pp..61-113.

${ }^{6}$ Ibid. pp.. 167-200.
} 
" A country with faithful and pious citizens, granted with blessings from earth and sky; which if there is any mistake then they will go back to the right path, with faith, after that safe from world infamy ,.... country citizens in the event of something that touches their security and national security matter they return to the ulil-amri and decisions will be made by those who are the true members of istinbat, they are making decisions and avoid cultural experts 'intellectual cowboysm'; the country of remembrance whose people worship God, rememberance and live in a state of spiritual care and common sense and movements. Countries which its members conduct amar makruf and nahi munkar with its terms " $"$.

Generally said that the "Zikir Nation" is a country that receives forgiveness and protection from Allah Subhanahu wa Ta`ala, as stated in al-Qur'an "baldatun țayyibatun wa rabbun Ghafur". The objective of Zikir Nation is to implement sharia (Maqasid Sharīah) to solve the problem of the Muslims and their safety ${ }^{8}$, cultivate the practice of $d h i k r^{9}$, develop family and $\operatorname{art}^{10}$, especially the art of calligraphy ${ }^{11}$.

To make Negara Zikir which is independant and peaceful is a religion demand that agreed by the scholars. Furthermore, Negara Zikir has its own mission and purpose which is to sustain Islam as a religious way of live; and sustain the Malay race as a sovereign nation as well as to sustain the royal system of government as the leader and protector of the religion, nation and country under the administration of a king (sultan) who comes from a Malay nation and islamic religion, who is fair, as well as sovereign and people-oriented. The process and tradition of Zikir Nation justifies Islamic development policies for the country which is to achieve peace and happiness in life whether in this world or in the hereafter as well as to obtain the blessings, pleasure, protection and forgiveness from Allah Subhānahu wa Ta ‘àlā.

The concept of "remembrance" (dhikr) in the broadest sense is not limited to the field of religion or worship specially conveyed through words and words that invoke the name of God alone, but covers all aspects of Muslim life either in theory or practical, spiritual, intellectual and physical. Another goal is simply to express gratitude and greatness and power of Allah Subhanahu wa $T a{ }^{\prime} \bar{l} \bar{a}$ up the entire universe.

This has been confirmed by Pg Dato Seri Setia Dr Haji Mohammad bin Pg Hj Abd. Rahman, ExMinister of Religious Affairs, Brunei Darussalam, that "the concept of dhikr 'remembrance' means:

"Remembering Allah. It should not be misunderstood, here remembering Allah means, praise, bertahmid, and Takbir simply, as 'zikrullah' or remembrance of Allah means wide, including the alleged 'of the Remembrance' were intellectuals or members of the member-academics and intellectuals who are experts in a particular field of science ". ${ }^{12}$

\footnotetext{
${ }^{7}$ Ibid. pp. 237-271

${ }^{8}$ Ibid. pp. $183-200$

${ }^{9}$ Ibid. pp. 203-220

${ }^{10}$ Ibid. pp.275-208

${ }^{11}$ Ibid. pp.223-234

${ }^{12}$ Ibid. p.163
} 
This statement is in line with the word of Allah:

Which means:

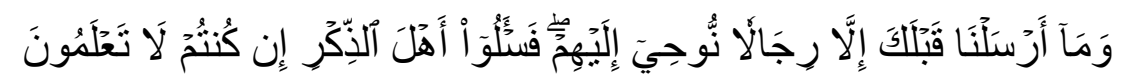

And we did not send before you any but men to whom we sent revelation, so ask the followers of the reminder if you do not know (al-Qur`an, Surah al-Nahl (16): 43; Surah al-Anbiyā' (21): 7).

Countries like these are guaranteed to be safe by Allah in this world and hereafter, as saying:

$$
\text { كلو ا من رزق ربكم واشكرو اله بلدة طيبة ورب غفور }
$$

Which means:

"Eat from the provision of your Lord and be grateful to Him, A good land (have you), and a forgiving Lord." (al-Qur'an, Surah Saba' (34): 15).

It means:

Another meaning of Negara Zikir has been stated by Mr.Mahmud Murshidi Othman, Deputy President of the National Develeopmen Plan (NDP), he defines "Negara Zikir" as an Islamic state or a peaceful country that has attained mercy from Allah Subhanahu Wa Ta'ala”.

The emergence of variation in defining the meaning of "Negara Zikir" is one of the evidence to prove Bruneian's commitment and responses towards KDYMM Paduka Seri Baginda Sutlan Haji Hassanal Bolkiah Muizzaddin Waddaulah Sultan dan Yang Di-pertuan Negara Brunei Darussalam's wish to create Brunei Darussalam as "Negara Zikir” (Dhikr Nation)

A speech was declared by the sultan (titah) about "Negara Zikir" which had been presented during celebration of Hari Raya Aidiladha, on 9hb Zulhijah 1428Hijrah, 19hb December 2007 Masehi.

"I, by Allah's will, gradually, am going to create Brunei as a "Zikir Nation" , and constantly giving our devotion to Allah, to ensure that we will always be in His guidance, as He had promised and mentioned in Al-Baqarah verse 152, "Remember Me, and I will remember you".

In accordance to the speech made by the KDYMM Paduka Seri Baginda Sultan Haji Hassanal Bolkiah Muizzaddin Waddaulah Sultan Dan Yang Di-Pertuan Negara Brunei Darussalam, the NDP (Natioanal Development Plan) had widened the scope of the term "Negara Zikir". This is because they had concluded that the former definition that was given by the researcher stated above infirmed and further amendment is essentially required. Below is stated the meaning of Negara Zikir and the terms from NDP based on the Sultan's speech that is:

“..all parties must understand what is the characteristic of Negara Zikir, its fundamentals and how it works"

The success of Negara Zikir (Dhikr Nation) is because of development. 


\section{3) Dhikr Nation Development}

According to the theory of social sciences and humanities, the development is part of a comprehensive process of socio-economic change for the development of society and the state. The Development meant here is the development of a well-planned and designed.

Development plans and design involves a human conscious effort to change life, which is termed as "social planning" (social engineering) involving multiple parties to make it work, namely the planners, implementers, beneficiaries and financiers. The whole generation is responsible for carrying out the development plan according to the abilities and capabilities of the individual, including political figures, professional groups, academics, merchants and financiers, as well as technical experts, farmers and entrepreneurs.

Development is divided into two characteristics, first ,"quantitative", and the second is "qualitative". Quantitative development is more easily calculated and measured because it is in a physical form, such as income per capita; while the qualitative is difficult to quantify and measure because it is in an abstract form that involves attitudes, values and traditions of society. Examples of these differences can be compared to the economic growth and development. Economic growth can be measured and assessed by looking at the rate of per capita Gross National Product (GNP), income, income distribution and the number of households, schools, cars and other factors. But in terms of development of the country, it is quite difficult to calculate and determine because it involves changes in attitudes, values and community traditions and work ethics that can prevent the progress of the national economy. On this basis, economic growth can be achieved without development, but development cannot be achieved without economic growth.

Economic growth is a prerequisite for development. Uncertain development occurs if economic growth cannot solve development problems, such as uneven distribution of wealth, repression and exploitation.

Development from the perspective of Islam is to raise the level of human dignity in the society. At the same time, leading the non-Muslims to Islam because their future lies in Islam. Without Muslims, they do not have a secure future. These are among some of the policies and strategies that must exist in developing Negara Zikir (Zikir Nation).

Building and developing the country is a pure business and a pure ambition, and one of the most important aspects of the theory of economic and political aspects in Islam. All sides should consider this matter because it is not fair to keep ourselves in a particular group. For example, the problem of conflict "khilafiyah" in schools of jurisprudence relating to recommended practices. At issue and the major challenges to the Malay community. Islam today is no longer a problem within the khilafiyyah in schools, but even more dangerous is "syncretism" which is a mixture of Islamic thought and culture with traditional culture of thinking and not Islamic and Western culture cannot be distinguished.

To replace religious values, morality and humanity. They develop the community and the state based on philosophy and theory alone: the decision is based on human reason alone, and not in accordance with the teachings of religion and law. Their development of philosophy is 
materialistic related to the character of "utilitarian" ie. for the happiness and prosperity of the world alone.

Although our country has accepted Islam centuries ago, but due to the passage of time in some generation which keeps on changing, in addition to the cultural shock and Western civilization that has a lot of influence on the thinking and way of life of the people in this country, people's understanding on Islam have increasingly strayed from its true foundation. Hence, policy and administrative management and development of the country was implemented in confusion due to the intervention of foreign powers, particularly the British based on administrative and socioeconomic development of the Islamic teachings.

The ability to re-establish the characteristics of faith and Islam in the individual, family, community and country is rather difficult to do without high commitment from the government through policy and clear strategies in terms of national legislation affecting the administration of the country, the leadership in society, education, socio-economic, language and culture. The national development policies and strategies should be built and achived according to Islamic perspective. In other words, the closer we are to Islam, the closer we are to Allah The Almighty.

\section{Triangle with in Vision 2035}

Brunei Vision 2035 is moving towards a developed country in three ways: economy, education and health within a given time period (2035). The goal is to eradicate poverty, ignorance and disease among the people in Brunei Darussalam.

To achieve Brunei Vision 2035, a strategic plan was formulated as follows:

1) Strategic education that will prepare the youth of Brunei for a world which is increasingly becoming more competitive and knowledge-based.

2) Strategic economy that will create new jobs and expand opportunities for people and business companies in Brunei Darussalam through the encouragement of investment, both foreign and domestic, in the downstream industries and the economic cluster outside the oil and gas industry.

3) Strategic Security to maintain political stability and preserve the sovereignty and defense capabilities with the ability to connect diplomatic and also assist the State in dealing with the threat of disease and natural disasters.

4) Strategic industry Development that will increase the quality of governance and leadership (governance) in the public and private sector, high-quality public services, consulting and regulatory framework that is modern and pragmatic and efficient government procedures with the minimum of bureaucracy.

5) Strategic local business development which will consider opportunities for small and medium enterprises (PKS) as well as facilitate the Brunei Malays to become leaders in business and industry through its competitive advantage.

6) Strategic infrastructure development that will ensure continued investment by government and through public-private sector partnership in the development of worldclass infrastructure to give priority to education, health and industry.

7) Strategic social guarantees that will ensure the country's continues to prosper, and Each one citizen will always get the attention it deserves. 
8) Strategic environment that will ensure the conservation of the natural and cultural environment. This will maintain the health and safety standards in line with good practice between nations.

9) Brunei towards achieving Vision 2035, which listed the strategies which should be developed by the government, the private sector and relevant organizations, and will be implemented and coordinated well as a strategy of the State. ${ }^{13}$

In brief, the strategic vision of Brunei in 2035 comprise of a total of 8 strategies including education, socio-economy, safety and the environment which can be combined in 3 types, namely "integration", "intensive" and "diversification". Strategy is what underlies the development of the State of remembrance that will be implemented in "continuous" or "vertical" (vertical) by a series of historical development of Brunei Darussalam and "change" or wide (horizontal) according to changes and needs in the era of globalization. The goal is to change and progress of society and the State and conducted earnest (intensive) with the help and cooperation of all government and private agencies and organizations associated with increased revenue and new sources other than oil and gas in diverse shapes (diversification) so that the strategy's vision and strategy in 2035 the idea of remembrance really achieved. The difference between the two strategies is only from the angle of approach, the approach of national development (Vision 2035) with the development approach of Islam (Dhikr Nation).

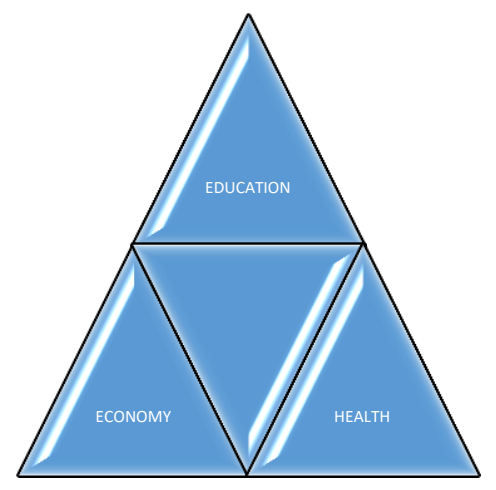

The matter has been decreed by His Majesty the Sultan, as follows:

"Optimal health allows one to fulfill his goals well, such as the search for knowledge and worship comfortably. Optimal health will no doubt enable the individual to perform the duties of the world and with optimal health" (Titah "Command"), in conjunction with the opening ceremony of 2012 in conjunction with his birthday 66th).

\section{Conclusion}

From what has been discussed above it can be concluded that the Theory of Global Prosperity (TGP) or Theory of Universal Prosperity (ToUP) is the base of the tree of all the problems that affect every aspect of human life whether in culture or civilization and become the main focus of the Prolegomena of Ibn Khaldun. Events that happen in 'Umran reasons can be identified

${ }^{13} \mathrm{http}: / /$ www.artgallery.com.bn/National_day/?page_id=289 
through the correct balance (معيار ا صحيحا) to distinguish the true from the false. A true balance which exists in the science of 'Umran. This knowledge is special and different from the other known sciences. It is not logic nor "civil and political science ") علم السياسة المدنية ) but it is the "new science" and "independent" for the purposes of management and development. This knowledge stems from the creation of the beginning of history, with laws and regulations that created by God. Only by understanding the laws and rules of nature that man alone can trace the cause of the occurrence of an event, such as 'Umran's event and causes of destruction. This was not noticed by the figures before Ibn Khaldun, including Aristotle. That is why the scope of 'Umran's study initiated from the early stages of a primitive human event that started from the Arab Bedouin community who live in the dessert until the formation of the village, the town and city. Bedouin life in the desert is characterized as primitive and unpretentious. They live in "selfsufficiency" and show restraint with what they barely have, that is not more than required or in excessive as it tempts feelings of greed, luxurious living, entertainment and a dissipate life. In contrast, the lives of Hadari (townspeople) are characterized by luxury and the pleasures of life that can bring a feeling of pride, arrogance, self-centeredness, and many other social problems that exist in the city. When this occurs it results in incapacitation 'Umran and fatigue and hence falling prey to evil from good (khayr). ${ }^{14}$

\section{References}

[1] Al-Qur`an al-Karim

[2] 'Abd al-Rahman bin Khaldun. 1993. Muqaddimah Ibn Khaldun. Beirut: Dar al-Kutub alIlmiyyah, al-Tab`ah al-Ula

[3] Mahayudin Hj Yahaya "Islamic-Based Development's Policies and Strategies: From Faculty of Islamic Development Management Perspective", International Journal of Education and Human Developments, Vol.3 No.2:Much 2017.

[4] Al-Mawrid, Qamus Arabic-English. 1988. Dr. Rohi Baalbaki. Beirut (al-Tab`ah al-Ula): Dar al'Ilm li al-Malayyin

[5] Negara Zikir: Azam, Keperluan dan Perlaksanaan, compilation of working papers Seminar Negara Zikir, Majlis Ilmu 2008, Prime Minister Department, Negara Brunei Darussalam, published by, Prime Minister Department, Negara Brunei Darussalam, 2010.

[6] Titah His Majesty the Sultan in conjunction with the opening ceremony of 2012 in conjunction with his birthday $66^{\text {th }}$

[7] http://www.artgallery.com.bn/National_day/?page_id=289

*Corresponding author.

E-mail address: Mahayuddin.yahaia@ unissa.edu.bn 